\title{
Ruptura traumática da veia jugular associada à tromboflebite: tratamento cirúrgico a campo
}

Mariana Cocco ${ }^{[a]}$, Flávia do Prado Augusto Amaro[a], Bruna Lampe Zielinski[a], Luiza Costa Barcellos ${ }^{[a]}$, Luis Fagner da Silva Machado ${ }^{[a]}$, lury Ribeiro de Paula $a^{[b]}$, Guilherme Vilvert Júnior ${ }^{[c]}$, Rudnei João de Souza ${ }^{[c]}$, Peterson Triches Dornbusch ${ }^{[a]}$

\footnotetext{
[a] Universidade Federal do Paraná (UFPR), Curitiba, PR, Brasil

${ }^{[b]}$ Hospital Veterinário Luis Leigue, Guaramirim, SC, Brasil

${ }^{[c]}$ Médicos veterinários, Gaspar, SC, Brasil
}

*Autor correspondente

e-mail: mariana.cocco@hotmail.com

\section{Resumo}

A tromboflebite de jugular é uma obstrução parcial ou completa do fluxo venoso, decorrente à formação de trombos, associada de inflamação da parede do vaso. Os principais fatores que influenciam no aparecimento do quadro são estase venosa, alterações na parede do vaso e alterações no sistema de coagulação. A enfermidade está associada a injeções com substância irritante, punção venosa e cateterização, trauma mecânico ao endotélio, perdas plasmáticas severas, infecção local por falta de assepsia e aos quadros endotoxêmicos. 0 tratamento preconizado para os casos de tromboflebite jugular em casos de infecção associada restringe-se à ligadura e remoção do vaso ou utilização de heparina. Casos de necrose tecidual extensa devido à tromboflebite muitas vezes estão associados a óbitos. 0 objetivo deste relato foi avaliar a eficácia do procedimento cirúrgico com a ligadura da veia jugular e da veia maxilar. Um equino, SRD, macho não castrado, 3 anos de idade, foi examinado em atendimento externo devido a uma flebite de jugular esquerda, resultante de injeções perivasculares com fenilbutazona e descaso na condução do tratamento. Os sinais clínicos observados foram dor e edema local, com leve edema da região parotídea. 0 agravamento do caso levou à necrose tecidual e ruptura da veia jugular no seu terço médio. A hemorragia foi intensa, sendo o sangramento controlado por compressão e sutura em massa de todo o tecido adjacente. Devido à necrose da veia jugular e tecido circundante, após 10 dias ocorreu um novo episódio de hemorragia. Nesse momento, optou-se pela ligadura e retirada da veia jugular no seu terço superior, desde a veia maxilar, associada à curetagem e limpeza da região perivascular necrótica e colocação de dreno. Todo o procedimento foi realizado com o paciente em estação e sob anestesia local, devido a restrições financeiras. Durante o período de 20 dias, o animal foi submetido à antibioticoterapia à base de benzipenicilina procaína (40.000UI/kg, 
IM, SID), diidroestreptomicina (16mg/kg, IM, SID) e piroxicam (1,2 mg/kg, IM, SID). 0 curativo tópico foi realizado com água corrente duas vezes ao dia, seguido de líquido de dakin, rifamicina spray e açúcar cristal, e seguido de massagem ao redor da ferida com pomada DM-Gel ${ }^{\circledR}$. Após quatro semanas, o paciente voltou aos trabalhos físicos normalmente. A oclusão da veia jugular devido à tromboflebite em equinos é relativamente comum. A necrose tecidual local deu-se em decorrência da grande concentração de substância irritante injetada, associada à contaminação bacteriana pela manipulação venosa feita sem as devidas técnicas de assepsia. A falta de infraestrutura como o exame ultrasonográfico da veia jugular, exames laboratoriais, materiais cirúrgicos e ambiente específico dificultam os procedimentos, decisões e até as condições de vida do paciente. A tromboflebite de jugular deve ser considerada uma emergência na clínica de equinos e o atraso no seu atendimento pode levar a complicações graves e risco de vida ao paciente. Apesar deste caso evoluir favoravelmente com o tratamento a campo, os autores recomendam a internação e cuidados intensivos para esses pacientes.

Palavras-chave: Tromboflebite. Jugular. Ligadura. 